\begin{tabular}{|l|l|l|l|l|}
\hline Internat. Rev. Hydrobiol. & $\mathbf{9 2}$ & 2007 & 3 & $229-241$ \\
\hline
\end{tabular}

\title{
DOI: 10.1002/iroh.200610916
}

\author{
Mafalda Gama, Ana lúcia Gonçalves, Verónica Ferreira, Manuel A. S. Graça \\ and CRISTINA CANHOTO*
}
JMAR-CIC and Department of Zoology, University of Coimbra, Largo Marquês de Pombal, 3004-517 Coimbra, Portugal; e-mail: ccanhoto@ci.uc.pt

\section{Decomposition of Fire Exposed Eucalyptus Leaves in a Portuguese Lowland Stream}

key words: Eucalyptus globulus, fungi, invertebrates, leaves

\begin{abstract}
We compared fire exposed with normal abscised eucalyptus leaves incubated in a stream running through eucalyptus plantations in central Portugal, in terms of breakdown rates, microbial activity, diversity and macroinvertebrate abundance. Although leaves exposed to fire had lower nutritional value, mass loss was similar for both leaf types $\left(k=0.0089-0.0095 \mathrm{~d}^{-1}\right.$ for fire and $k=0.0084-0.00103 \mathrm{~d}^{-1}$ for normal leaves). Fungal biomass was similar among treatments, whereas sporulation and microbial respiration were lower in fire exposed leaves. Both leaf types had similar aquatic hyphomycetes communities. Physical fragmentation was important in fire exposed leaves breakdown. Invertebrates colonized leaves in low numbers in both treatments. Alteration of leaf litter quality determined by fires in streams does not seem to determine changes in ecosystem functioning in a short term.
\end{abstract}

\section{Introduction}

Eucalyptus globulus LABILL. was introduced in the Iberian Peninsula in 1829. Presently, this native evergreen Australian species is very common and widespread in Portugal where it occupies more than $21 \%$ of the forested area. Eucalyptus plantations have replaced large areas of native deciduous forest because of their fast growth, which allows the quick afforestation of timber harvested and burned areas (D. G. F., 2005).

Eucalyptus leaves are a primary source of energy and carbon for aquatic food webs in streams running through eucalyptus monocultures (Pozo et al., 1997a, b; MoLINERO and Pozo, 2003). Litter decomposition is a vital ecological process in these small streams, mostly carried out by fungi and invertebrates (GESSNER et al., 1999; HIEBER and GESSNER, 2002). Aquatic fungi convert leaf mass into fungal biomass and spore production (GESSNER and CHAuvet, 1994; BALDY et al., 1995) and enhance leaf consumption by shredding invertebrates (GRAÇA et al., 2001). One important factor controlling litter decomposition rates is its intrinsic nutritional quality frequently expressed as lignin, $\mathrm{N}$ and/or P contents (GESSNER and Chauvet, 1994; Royer and Minshall, 2001; DíEz et al., 2002; Stelzer et al., 2003). Changes in eucalyptus leaves quality can arise from leaves being exposed to high temperatures during forest fires. During these catastrophic events, some leaves may not burn and detach from the trees after the fires. Adult eucalypt leaves are classified as intermediate in their resistance to combustion, and juvenile leaves are highly resistant to flaming (REGUEIRA

* Corresponding author 
et al., 2002). The unburned eucalyptus leaves may be physically and chemically altered and remain in the catchment's soil or accumulate in the stream channel, constituting a potential food source for the stream communities when flow resumes.

Wildfires are frequent in Mediterranean areas. In Portugal, in the last 25 years, fires consumed more than three million ha of forest (D. G. F., 2005). Most of these areas were eucalyptus monocultures. Consequences of these fires on the terrestrial (reviewed by CERTINI, 2005) and aquatic systems are far from being completely evaluated. Previous research indicate that post fire instream alterations are largely due to the loss of terrestrial vegetation which can lead to altered stream morphology and substratum characteristics (MinsHALL et al., 2003a), elevated runoff, increased ions concentration and increased suspended sediments and particulate organic matter (HAUER and SPENCER, 1998; Minshall et al., 2001a; FERREIRA et al., 2005), although changes in water quality may last for as short as 3 months (STEPHENS et al., 2005). Moreover, the disappearance of the riparian vegetation may result in a shift from a heterotrophic to an autotrophic system as the allochthonous litter input to the stream is reduced and the water surface exposed to solar irradiation is increased (MINSHALl, 2003b; Minshall et al., 2001b, 2003a; MinuC and Minshall, 2005). However, very little is known about the fate of the large amount of leaves that remain in the riparian areas and saturate the stream channel after fires.

In this study, we compared the breakdown of eucalyptus leaves normally abscised and leaves exposed to fire in terms of breakdown rates, microbial and invertebrate colonization. Data will allow us to better predict the dynamics of litter processing in streams running through eucalyptus plantations in the Mediterranean systems.

\section{Methods}

\subsection{Study Site and Water Parameters}

This study was carried out in a lowland 3rd order stream running through eucalyptus plantations (Ribeira do Botão, Central Portugal; $40^{\circ} 18^{\prime} 22^{\prime \prime} \mathrm{N}, 8^{\circ} 23^{\prime \prime} 37^{\prime \prime} \mathrm{W}$ ). These plantations did not burn, as did most plantations in central Portugal during summer 2005. The stream water was well oxygenated, circumneutral, mesotrophic and ion rich (Table 1). Alder (Alnus glutinosa (L.) GAERTN.) trees were present in the riparian area, in the study reach.

During the study period (November, 2005 to February, 2006) water $\mathrm{pH}$ (Jenway 3150), conductivity and temperature (WTW LF 330) and dissolved oxygen (Jenway 9200) were recorded seven times. Water depth and current velocity (Valeport 15277) were also recorded three times and used to estimate discharge. In addition, $5 \mathrm{~L}$ of stream water were collected in acid washed plastic bottles. Water was

Table 1. Characteristics of the study stream and physical and chemical characteristics of the stream water $(\min -\max ; * n=3, * * n=7)$.

\begin{tabular}{lc}
\hline Catchment $\left(\mathrm{km}^{2}\right)$ & 17.897 \\
Discharge $\left(\mathrm{m}^{3} \mathrm{~s}^{-1}\right)^{*}$ & $0.21-0.34$ \\
Temperature $\left({ }^{\circ} \mathrm{C}\right)^{* *}$ & $8-15$ \\
$\left.\mathrm{O}_{2}(\mathrm{mg} \mathrm{L})^{-1}\right)^{* *}$ & $10.1-11.6$ \\
Conductivity $\left.(\mu \mathrm{S} \mathrm{cm})^{-1}\right)^{* *}$ & $174-199$ \\
$\mathrm{pH}^{* *}$ & $6.8-7.4$ \\
$\mathrm{~N}^{*} \mathrm{NO}_{3}\left(\mathrm{mg} \mathrm{L}^{-1}\right)^{*}$ & $1.72-2.36$ \\
$\mathrm{SRP}\left(\mu \mathrm{g} \mathrm{L}^{-1}\right)^{*}$ & $4.76-6.40$ \\
$\mathrm{CaCO}\left(\mathrm{mg} \mathrm{L}^{-1}\right)^{*}$ & $0-1.47$ \\
$\mathrm{Ca}^{2+}\left(\mathrm{mg} \mathrm{L}^{-1}\right)^{*}$ & $16.24-25.28$ \\
$\mathrm{Na}^{+}\left(\mathrm{mg} \mathrm{L}^{-1}\right)^{*}$ & $11.91-15.94$
\end{tabular}


transported to the laboratory in a cooler, filtered and 2 subsamples frozen at $-18{ }^{\circ} \mathrm{C}$ for later determination of cations and anions by ion chromatography (Dionex DX-120). Soluble reactive phosphorus (SRP) was determined by the ascorbic acid method (APHA, 1995).

\subsection{Leaf Breakdown}

Leaves of Eucalyptus globulus LABILL. were collected from the same stand before the peak of litter abscission (June/July 2005; control leaves) or in a riparian zone after a recent fire (August 2005; fire exposed leaves). All leaves were picked up from the ground, air dried in the dark and stored until needed. Groups of 4 control leaves (3.72-7.64 g initial air-dry mass) or 4 fire exposed leaves (3.26-5.20 g initial air-dry mass) were enclosed into $10 \times 15 \mathrm{~cm}$ coarse mesh $(\mathrm{CM}, 10 \mathrm{~mm}$ mesh; exposed to invertebrates) and fine mesh (FM, $0.5 \mathrm{~mm}$ mesh; protected from most invertebrates). A total of 96 bags (24 per treatment) were tied to nylon ropes and exposed in the stream on November 15, 2005. This day, 4 extra bags per treatment were taken to the stream and brought back to the laboratory to estimate the initial leaf ash free dry mass (AFDM) from each leaf bag taking into account mass loss due to handling. After 2, 7, 13, 28, 62 and 90 days of submersion 4 bags of each treatment were randomly retrieved, placed in individual plastic bags with some stream water and transported in a cooler to the laboratory. Each sample was gently rinsed with distilled water on top of a $500 \mu \mathrm{m}$ mesh sieve to retain invertebrates (see below), and 3 sets of 5 leaf disks were cut with a cork borer (12 $\mathrm{mm}$ diameter) from 5 different leaves. Leaf disks were used to determine microbial respiration, leaf concentration in ergosterol and aquatic hyphomycetes sporulation (see below). The remaining leaves were dried for $48 \mathrm{~h}$ at $105{ }^{\circ} \mathrm{C}$ for dry mass determination, and ashed for $4 \mathrm{~h}$ at $550{ }^{\circ} \mathrm{C}$ for $\%$ ash and AFDM determination. Mass loss was expressed as a percentage of initial mass $(n=4)$ after corrected for the disks that were retrieved (see below).

\subsection{Initial Litter Quality}

Some physical and chemical parameters likely to affect litter quality were measured in control and fire exposed leaves. Leaf material was used for the determination of initial lignin (GoERING and VAN SOEST, 1970), phosphorus, nitrogen (GRAÇA et al., 2005) and total polyphenolics (Folin-Ciocalteau assay; GRAÇA et al., 2005) content. The calorific value of both leaf types was measured according to PAIVA et al. (2006).

\subsection{Microbial Respiration}

One set of leaf disks was used to assess microbial respiration rates associated with decomposing leaves (GRAÇA et al., 2005). The flow-through system, set at $15^{\circ} \mathrm{C}$, consisted of a peristaltic pump with adjustable flow provided with Watson-Marlow orange/green tubes. One end of the tubes was connected to the respiration chambers ( $8 \mathrm{ml}$ glass syringes) and the other end entered a reservoir containing filtered stream water $100 \%$ oxygenated. Measurements of oxygen concentrations in water were made only after the chambers' volume was totally replaced. The water flowing through the chambers was collected with a $1 \mathrm{~mL}$ syringe and injected into a $0.1 \mathrm{~mL}$ micro-chamber adapted to an oxygen electrode (Strathkelvin Inst. 781) and readings made after 30 seconds. After 3 measurements (with $1.5 \mathrm{~h}$ interval) the out-flow was determined with a $5 \mathrm{~mL}$ calibrated glass vial for 20 minutes. Oxygen consumptions were expressed as $\mathrm{mg} \mathrm{O}_{2} \mathrm{~g}^{-1}$ leaf AFDM $\mathrm{h}^{-1}$.

\subsection{Fungal Biomass}

Fungal biomass was estimated after ergosterol content (GeSSNER and SCHMitT, 1996; GRAÇA et al., 2005). Five leaf disks from each sample were stored in $10 \mathrm{ml}$ of $\mathrm{KOH} / \mathrm{methanol}$ at $-18{ }^{\circ} \mathrm{C}$ until ergosterol extraction. Ergosterol was extracted in a water bath $\left(80^{\circ} \mathrm{C}\right)$ for $30 \mathrm{~min}$., purified by solid-phase 
extraction (Waters Sep-Pak Vac $\mathrm{RC} \mathrm{tC}_{18}$ cartridges) and quantified by high performance liquid chromatography (HPLC) by measuring absorbance at $282 \mathrm{~nm}$. The HPLC system (Dionex DX-120) was equipped with the reverse phase $\mathrm{C}_{18}$ column (Brownlee SPHERI-5RP-18, Applied Biosystems) maintained at $33{ }^{\circ} \mathrm{C}$. The mobile phase was $100 \%$ methanol and the flow rate was set at $1.5 \mathrm{~mL} \mathrm{~min}{ }^{-1}$. Ergosterol was converted into fungal dry mass by assuming an ergosterol concentration of $5.5 \mu \mathrm{g} \mathrm{mg}^{-1}$ fungal dry mass (GESSNER and ChAUVET, 1993). Results were expressed as mg fungal biomass $\mathrm{g}^{-1}$ leaf AFDM.

\subsection{Fungal Sporulation}

Five leaf disks from each bag were incubated in $100 \mathrm{~mL}$ Erlenmeyer flasks with $25 \mathrm{~mL}$ of filtered stream water (glass fiber filter, Millipore APFF) on an GFL 3017 orbital shaker (100 rpm) for $48 \mathrm{~h}$ at $15^{\circ} \mathrm{C}$ to induce sporulation by aquatic hyphomycetes (GraÇA et al., 2005). The conidia suspensions were fixed with $2 \mathrm{~mL}$ of $37 \%$ formalin for later counting and identification. When preparing slides, $100 \mu \mathrm{L}$ of $0.5 \%$ Triton X-100 solution were added to the suspension to ensure a uniform distribution of conidia, stirred and an aliquot of the suspension was filtered (pore size $5 \mu \mathrm{m}$, Millipore SMWP). Filters were stained with $0.05 \%$ cotton blue in lactic acid (60\%), and spores were identified (GrAÇA et al., 2005 ) and counted with a compound microscope at $200 \times$. Leaf disks were used to calculate remaining AFDM (as above) and the value was used to correct for disk removal from leaves. Sporulation rates were expressed as number of conidia released $\mathrm{mg}^{-1}$ leaf AFDM day ${ }^{-1}$.

\subsection{Invertebrate Colonization}

Invertebrates from coarse mesh bags retained over a $500 \mu \mathrm{m}$ mesh sieve were preserved in $95 \%$ ethanol for later counting and identification. Identification was done to genus/species when possible, except for Oligochaeta (family) and Diptera (sub-family or tribe) and individuals assigned to functional feeding groups (scrapers, shredders and others) according to TACHET et al. (2000).

\subsection{Data Analysis}

Breakdown rates $(k)$ were estimated by linear regression of $\ln$ transformed data (negative exponential model $\mathrm{M}_{\mathrm{t}}=\mathrm{M}_{\mathrm{o}} \cdot \mathrm{e}^{-k \mathrm{t}}$, where $\mathrm{M}_{\mathrm{o}}$ is the initial mass, $\mathrm{M}_{\mathrm{t}}$ is the remaining mass at time $\mathrm{t}$ and $k$ is the decomposition rate). Slopes of regression lines (ln transformed data) were compared by ANCOVA with leaf and mesh type as categorical variables and time as continuous variable (ZAR, 1999). Remaining mass data (arcsine transformed) at day 2 were also compared among treatments by 2-way ANOVA (leaf type and mesh type as categorical variables) to assess differences due to leaching.

Microbial oxygen consumption, fungal biomass and aquatic hyphomycetes sporulation rates were compared among treatments by 3-way ANOVA (leaf type, mesh type and time as categorical variables) followed by Tukey's test when necessary. Cumulative conidial production at the last sampling date was calculated by summing up values of daily production at each sampling date and linearly approximated values for each day between sampling dates. Percentage of initial litter AFDM converted into conidia was calculated assuming a mean conidia mass of $8.17 \times 10^{-7} \mathrm{mg}$ (calculated from BäRLOCHER and Schweizer (1983) and ChAuvet and Suberkropp (1998)) and initial disks AFDM of 98 (control leaves) and 105 (fire exposed leaves) mg.

Cumulative species richness of aquatic hyphomycetes over time was compared among treatments by ANCOVA with leaf and mesh type as categorical variables and time as continuous variable. Shannon's diversity and Pielou's evenness indices (for day 7 to 90) of aquatic hyphomycete communities colonizing leaves were calculated from conidial abundances (PRIMER 6) and compared among treatment by 3-way ANOVA (leaf type, mesh type and time as categorical variables) followed by Tukey's test when necessary. Differences in overall aquatic hyphomycete communities between leaf types (for day 7 to 90) were assessed by analysis of similarities (ANOSIM, PRIMER 6; ClARKE and GorLeY, 2001). Data on conidial abundances from day 2 were excluded from indices and analysis of similarities because in most samples there was yet no conidia production. Total invertebrate, scrapers and shredders abun- 
dance in coarse mesh bags were compared between leaf types by 2-way ANOVA with leaf type and time as categorical variables. Data was transformed when necessary to achieve normality (ZAR, 1999) and analyses were performed with STATISTICA 6 software, unless otherwise indicated.

\section{Results}

\subsection{Leaf Quality and Breakdown}

Lignin content was higher for fire exposed than for control leaves while the opposite was true for phosphorus, nitrogen, energy and polyphenols content (Table 2). Leaching was intense and after only 2 days in water mass loss varied between 15\% (fire exposed CM) and $25 \%$ (fire exposed FM), although no significant differences were detected among treatments (2-way ANOVA, $P=0.781$ ). Leaves lost between 48\% (control FM) and 57\% (control CM) of their initial mass after 90 days incubation in the stream. Breakdown rates $(k)$ ranged from $0.0084 \mathrm{~d}^{-1}$ (control FM) to $0.0103 \mathrm{~d}^{-1}$ (control CM) with no significant differences among treatments (ANCOVA, $P=0.833$ for leaf type and 0.536 for mesh type) (Table 3 ).

\subsection{Microbial Respiration}

Microbial oxygen consumption in coarse mesh bags rapidly increased until day 28 $\left(0.32 \mathrm{mg} \mathrm{O}_{2} \mathrm{~g}^{-1} \mathrm{AFDM} \mathrm{h}^{-1}\right.$ in fire exposed leaves and $0.39 \mathrm{mg} \mathrm{O}_{2} \mathrm{~g}^{-1} \mathrm{AFDM} \mathrm{h}^{-1}$ in control leaves) and declined sharply thereafter. Microbial oxygen consumption in fine mesh bags peaked at lower levels $\left(0.17 \mathrm{mg} \mathrm{O}_{2} \mathrm{~g}^{-1}\right.$ AFDM h${ }^{-1}$ in fire exposed leaves and $0.25 \mathrm{mg} \mathrm{O}_{2} \mathrm{~g}^{-1}$

Table 2. Lignin, nitrogen, phosphorus, phenols and calorimetric content of control and fire exposed eucalyptus leaves (min-max; $n=2$ for lignin, $n=3$ for $\mathrm{N}$ and $\mathrm{P}, n=4$ for polyphenolics and energy). DM = Dry Mass.

\begin{tabular}{lcc}
\hline & Control & Fire exposed \\
\hline Lignin (\% leaf DM) & $13.1-13.7$ & $15.9-16.5$ \\
Nitrogen (\% leaf DM) & $1.27-1.52$ & $0.62-0.75$ \\
Phosphorus (\% leaf DM) & $0.110-0.123$ & $0.049-0.052$ \\
Phenols (\% leaf DM ) & $4.7-6.2$ & $4.5-4.9$ \\
Energy $\left(\mathrm{J} \mathrm{mg}^{-1}\right)$ & $27.2-29.3$ & $23.1-23.6$ \\
\hline
\end{tabular}

Table 3. Decomposition rates $(k)$ of control and fire exposed eucalyptus leaves in coarse and fine mesh bags. $\mathrm{CL}=$ confidence limits. Comparisons were made among leaf and mesh type (ANCOVA, same letters indicate no significant differences $(P>0.05)$ among slopes).

\begin{tabular}{lccccc}
\hline Leaves & Mesh & $k\left(\mathrm{~d}^{-1}\right)$ & $95 \% \mathrm{CL}$ & $R^{2}$ & ANCOVA \\
\hline Control & Coarse & 0.0103 & 0.0015 & 0.84 & $\mathrm{a}$ \\
& Fine & 0.0084 & 0.0009 & 0.79 & $\mathrm{a}$ \\
\multirow{2}{*}{ Fire exposed } & Coarse & 0.0089 & 0.0009 & 0.82 & $\mathrm{a}$ \\
& Fine & 0.0095 & 0.0009 & 0.81 & $\mathrm{a}$ \\
\hline
\end{tabular}




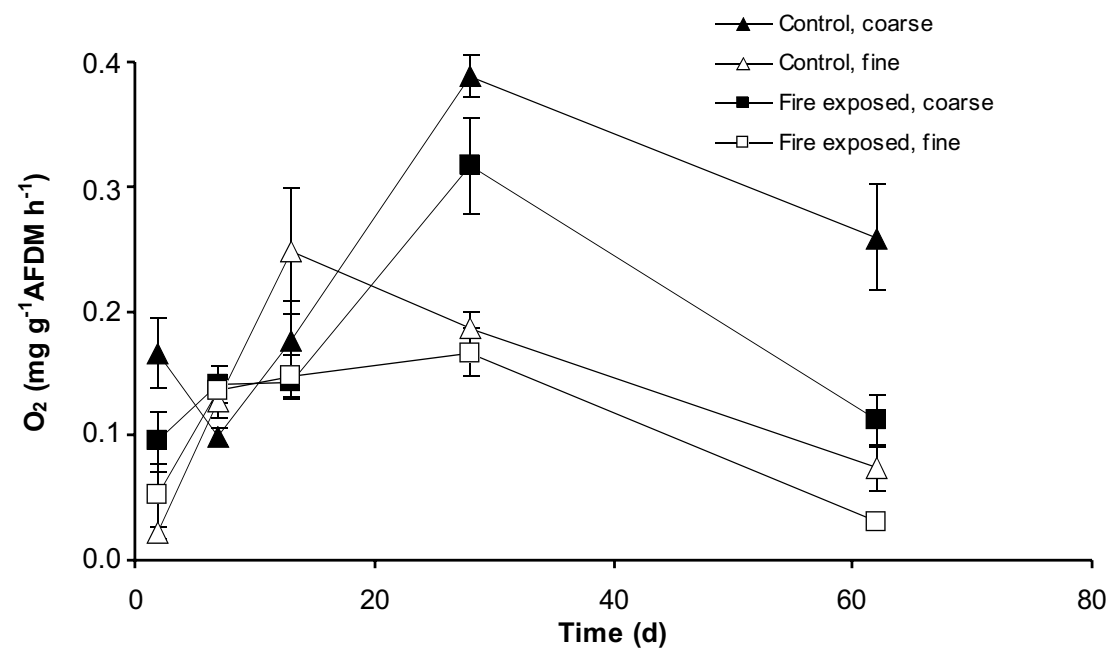

Figure 1. Microbial respiration (mean $\pm 1 \mathrm{SE}$ ) in control and fire exposed eucalyptus leaves in coarse and fine mesh bags.

$\mathrm{AFDM} \mathrm{h}^{-1}$ in control leaves) and earlier for control than for fire exposed leaves (d13 vs. d28) (Fig. 1). Microbial oxygen consumption was significantly higher in control than in fire exposed leaves in coarse mesh bags (3-way ANOVA, $P=0.001)$ and in coarse mesh than in fine mesh bags (3-way ANOVA, $P<0.001)$.

\subsection{Fungal Biomass}

Fungi were already in leaves before the beginning of the experiment (22 and $42 \mathrm{mg} \mathrm{g}^{-1}$ AFDM in control and fire exposed leaves, respectively). Fungal biomass declined, however, to values $<5 \mathrm{mg} \mathrm{g}^{-1}$ AFDM after 2 days incubation, increasing thereafter until the last



Figure 2. Mycelial biomass (mean $\pm 1 \mathrm{SE}$ ) in control and fire exposed eucalyptus leaves in coarse and fine mesh bags. 
sampling date in control leaves (79-82 $\mathrm{mg} \mathrm{g}^{-1}$ AFDM in CM and FM, respectively) or peaking before in fire exposed leaves (by day 28 for CM with $70 \mathrm{mg} \mathrm{g}^{-1}$ AFDM and day 62 for FM with $63 \mathrm{mg} \mathrm{g}^{-1}$ AFDM) (Fig. 2). There were no significant differences in fungal biomass either between leaf or mesh types (3-way ANOVA, $P=0.384$ and 0.506 , respectively).

\subsection{Fungal Sporulation}

Sporulation by aquatic hyphomycetes did not occur until 2 weeks after immersion, but it peaked by day 28 in all treatments with 254 conidia $\mathrm{mg}^{-1}$ AFDM d ${ }^{-1}$ in fire exposed leaves (FM) and 3226 conidia $\mathrm{mg}^{-1}$ AFDM d ${ }^{-1}$ in control leaves (CM) (Fig. 3). Differences between leaf types were found only for fine mesh bags (3-way ANOVA, $P<0.001$ ) with values being higher in normal leaves than in fire leaves. For fire leaves, sporulation was significantly higher in coarse than in fine mesh bags (3-way ANOVA, $P=0.001)$. The percentage of initial litter AFDM converted into conidia ranged from 9.1 (FM) to $10.0(\mathrm{CM})$ in control leaves and $1.6(\mathrm{FM})$ to $3.7(\mathrm{CM})$ in fire exposed leaves; i.e., 3-5 times higher in control leaves.

\subsection{Aquatic Hyphomycetes}

A total of 22 species of aquatic hyphomycetes was found in this study (Table 4). Lunulospora curvula and Tetrachaetum elegans were the most representative species in all treatments. T. elegans was an early colonizer and dominated conidial production in the first 4 weeks of incubation in both leaf and mesh types (up to $98 \%$ contribution to the total number of conidia). L. curvula replaced T. elegans after day 28 and dominated (up to 87\%) until the last sampling date. Between 76 and $88 \%$ of species contributed with $<5 \%$ to the total conidial production in a given treatment.

Cumulative species richness over time was higher in coarse mesh than in fine mesh bags (ANCOVA, $P=0.014$ ), although there were no significant differences between leaf types (ANCOVA, $P=0.471$ ). Shannon's diversity index was not significantly different between treatments (3-way ANOVA, $P=0.297$ for leaf type and 0.578 for mesh type) (Table 4). Pielou's evenness index was significantly higher for fire exposed than for control leaves in

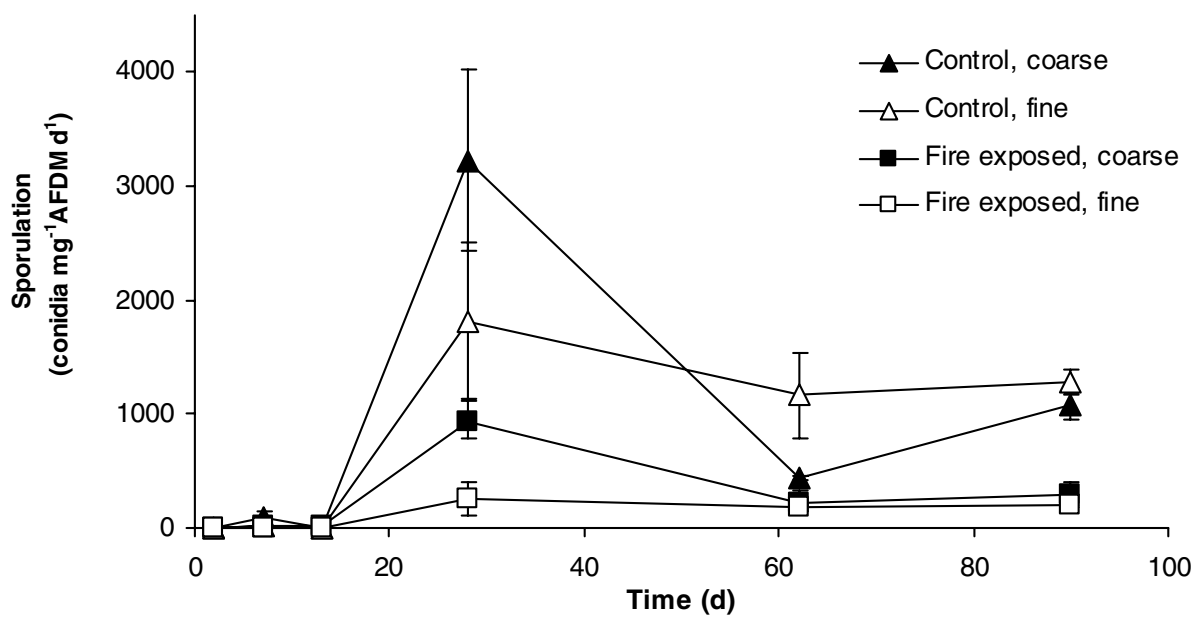

Figure 3. Fungal sporulation rate (mean $\pm 1 \mathrm{SE}$ ) of aquatic hyphomycetes in control and fire exposed eucalyptus leaves in coarse and fine mesh bags. 
Table 4. Mean relative abundances (\%, for day 7 to 90 ) of aquatic hyphomycete conidia from control and fire exposed eucalyptus leaves in coarse and fine mesh bags. Total number of species and mean Shannon's diversity and mean Pielou's evenness indices (SE) are given. Comparisons were made among leaf and mesh types (3-way ANOVA, same letters indicate no significant differences $(P>0.05)$ among treatments).

\begin{tabular}{|c|c|c|c|c|}
\hline & \multicolumn{2}{|c|}{ Control } & \multicolumn{2}{|c|}{ Fire exposed } \\
\hline & Coarse & Fine & Coarse & Fine \\
\hline Alatospora acuminata INGOLD s.l. & 4.39 & 0.53 & 3.78 & 3.01 \\
\hline Alatospora pulchella MARVANOVÁ & 0.09 & 0.28 & 0.04 & 0.13 \\
\hline Anguillospora crassa INGOLD & 0.15 & 0.10 & 0.36 & 0.39 \\
\hline Anguillospora filiformis GREATH. & 0.44 & 0.40 & 1.00 & 0.56 \\
\hline Articulospora tetracladia INGOLD & 0.20 & 0.13 & 0.12 & 0.82 \\
\hline Clavariopsis aquatica DE WILD. & 0.07 & 0.03 & 0.23 & 0.07 \\
\hline Heliscus submersus Huds & 6.05 & 1.37 & 4.96 & 7.28 \\
\hline Heliscus lugdunensis SACC. and THERRY & 0.64 & 4.87 & 0.86 & 18.46 \\
\hline Lemonniera aquatica DE WILD. & & & 0.05 & \\
\hline Lemonniera terrestris TUBAKI & & & 0.05 & \\
\hline Lunulospora curvula INGOLD & 35.70 & 54.55 & 24.26 & 28.89 \\
\hline Margaritispora aquatica INGOLD & 0.04 & & 0.03 & 0.59 \\
\hline $\begin{array}{l}\text { Stenocladiella neglecta (MARVANOVÁ } \\
\text { and DeSCALS) MARVANOVÁ and DESCALS }\end{array}$ & 0.04 & & & \\
\hline Tetracladium marchalianum DE WILD. & 1.95 & 0.44 & 3.57 & 4.51 \\
\hline Tetrachaetum elegans INGOLD & 43.88 & 34.57 & 47.58 & 27.75 \\
\hline Tricladium chaetocladium INGOLD & 0.94 & 0.83 & 3.53 & 1.29 \\
\hline Tricladium splendens INGOLD & & & & 0.09 \\
\hline Triscelophorus acuminatus NAWAWI & 3.81 & 1.33 & 7.68 & 3.96 \\
\hline Triscelophorus monosporus INGOLD & 1.54 & 0.46 & 1.75 & 2.14 \\
\hline Varicosporium sp. & 0.04 & & 0.07 & \\
\hline Unidentified tetraradiate & & 0.08 & 0.09 & 0.06 \\
\hline small sigmoid $(<60 \mu \mathrm{m})$ & & 0.03 & & \\
\hline Total no. species & 17 & 16 & 19 & 17 \\
\hline Shannon's diversity, H' & $0.81(0.16)^{\mathrm{a}}$ & $0.59(0.05)^{\mathrm{a}}$ & $0.98(0.19)^{\mathrm{a}}$ & $1.12(0.15)^{\mathrm{a}}$ \\
\hline Pielou's evenness, J & $0.47(0.06)^{\mathrm{a}}$ & $0.40(0.04)^{\mathrm{ab}}$ & $0.55(0.08)^{\mathrm{ab}}$ & $0.63(0.06)^{b}$ \\
\hline
\end{tabular}

fine mesh bags (3-way ANOVA, $P=0.008$ ), but no significant difference was found between mesh types for either substrate (3-way ANOVA, $P=0.240$ ). Fungal communities colonizing submerged substrates were always more different among sampling dates (ANOSIM, $R>0.83$ and $P=0.001$ ) than among leaf types (ANOSIM, $R<0.51$ and $P<0.022)$ for both mesh types.

\subsection{Invertebrate Colonization}

Invertebrate colonization of leaf bags was low $\left(<10\right.$ ind $\mathrm{g}^{-1}$ AFDM; $<3$ shredders $\mathrm{g}^{-1}$ AFDM). Invertebrate abundance increased until the last sampling date in control leaves while in fire exposed leaves it peaked by day 7 after which it decreased to peak again at the last date (Fig. 4). Total invertebrate abundances in coarse mesh bags were not significantly different between leaf types (2-way ANOVA, $P=0.196$ ), although shredders demonstrated a preference for fire exposed leaves when compared to control leaves (2-way ANOVA, $P=0.001$ ). 


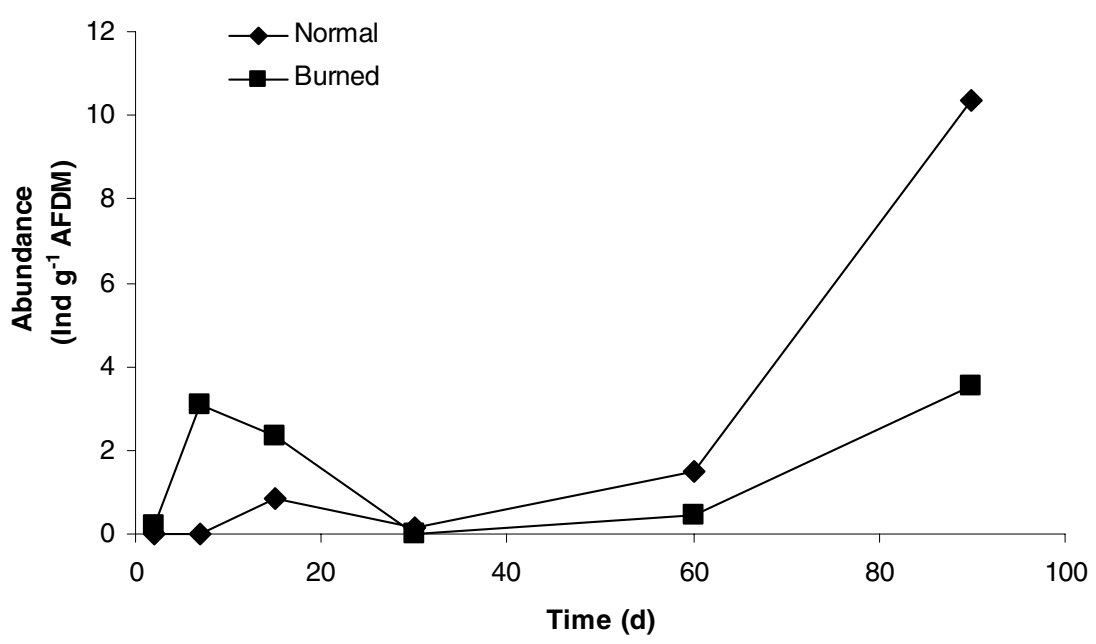

Figure 4. Invertebrate abundance (mean $\pm 1 \mathrm{SE}$; SE bars smaller than symbols) associated with control and fire exposed eucalyptus leaves in coarse mesh bags.

\section{Discussion}

Every summer wild fires consume vast areas of Eucalyptus plantations in Central Portugal (DoERr and CERDÀ, 2005) supplying large amounts of shed fire exposed leaves to the riparian areas and stream channels. Exposition of eucalyptus leaves to high temperatures during fires resulted in the impoverishment of its nutritional quality. However, normal abscised and fire exposed leaves had similar breakdown rates $\left(k=0.0084-0.0103 \mathrm{~d}^{-1}\right)$, with values included in the upper range of those previously reported for eucalyptus leaves (САNНОTO and GraÇA, 1996; Molinero et al., 1996; Pozo et al., 1998). This suggests an incorporation of fire exposed leaves into secondary production in a reasonable time span. But results must be interpreted with caution as breakdown values $(k)$ are single constants that describe an often complex process (WEBSTER and BENFIELD, 1986). This simplified mathematical description of the process may mask (as we believe happened in this case) important biological differences in the degradation process and always expresses results from specific environmental conditions. Biomass of aquatic fungi accounted for 6 to $8 \%$ of the remaining leaf detritus, which is in accordance with results reported for other leaf types (GESSNER and Chauvet, 1994; Baldy et al., 1995), including eucalyptus leaves (Pozo et al., 1998). However, although fungal biomass was similar among treatments, its dynamics varied between leaf types. An expected increase over time was observed in controls (Pozo et al., 1998) whereas in fire exposed leaves fungal biomass decreased after an incubation of 4 to 9 weeks. This may be the result of a faster exhaustion of more readily digested leaf tissues when compared with control leaves that had higher initial nutrient content.

Overall microbial activity (oxygen consumption) associated with decomposing leaves was also in the range previously reported for submerged substrates (NIYOGI et al., 2003; GULIS and Suberkropp, 2003a; Stelzer et al., 2003), and was higher in control than in fire exposed leaves. Fungal activity may be partially responsible for this difference as the pattern in microbial oxygen consumption and fungal sporulation was similar in control leaves. On the other hand, we cannot rule out the possibility that bacteria increase their activity on leaves that are more nutritious without affecting processing rates significantly. Other stud- 
ies report that bacterial activity is stimulated on high quality substrates (GULIS and SUBERKROPP, 2003b; STELZER et al., 2003) and/or in nutrient enriched streams, although bacterial contribution to leaf decomposition is highly surpassed by fungi (PASCOAL and CÁSSIO 2004).

The lower microbial activity in fire exposed leaves was not translated into lower breakdown rates as would be expected. A compensatory effect of physical degradation due to absence/reduction of the cuticle in this leaf material (pers. obs.) might have occurred. The lack of this protective layer may increase the susceptibility of the leaves to the effect of current velocity. CANHOTO and GRAÇA (1999), in a study with eucalyptus leaves, stated that the cuticle is the warrant of the elongated integrity of the senescent leaves after immersion.

Twenty-two species of aquatic hyphomycetes were identified in this study, with no major differences in community structure among treatments. Tetrachaetum elegans and Lunulospora curvula dominated the conidial production in the first 2 weeks and after day 28, respectively, in all treatments. T. elegans has been reported to be an earlier colonizer (BÄRLOCHER, 1991; GESSNER et al., 1993) while L. curvula usually appears in later stages (CHAUVET et al., 1997). Despite the recognized preference of this species for warmer waters (reviewed by BÄRLOCHER, 1992; in the study stream water temperature was $15^{\circ} \mathrm{C}$ ) L. curvula has been frequently reported as being associated with eucalyptus (BÄrLOCHER et al., 1995; CHAUVET et al., 1997; BÄRLOCHER and GRAÇA, 2002; FERREIRA et al., 2006a).

The abundance of macroinvertebrates in decomposing leaves was very low, which is probably related with the presence of alder leaves in the study reach. Shredding invertebrates have preferences for less recalcitrant high nutrient substrates, as alder, when compared with eucalyptus leaves (CANHOTO and GRAÇA, 1995, 1999). Nevertheless, and although the low number of shredders suggest caution, this functional group seemed to prefer fire exposed over control leaves. This could be attributed to their lower contents in secondary compounds as polyphenolics and/or to the loss of essential oils promoted by fire; both are inhibitors of invertebrates' consumption (САNHOTO and GRAÇA, 1995, 1999). In fact, and in spite of the high heat combustion of the eucalyptus oils, we could not observe (or smell) the oil vesicles in the inner leaf tissues in leaves exposed to fire (vs. control leaves; pers. obs.). However, Minuc and Minshall (1995) reported that only one out of eleven macroinvertebrate species was able to grow when fed with burned organic matter. Considering that normal eucalyptus leaves are a poor substratum for invertebrates (CANHOTO and GRAÇA, 1995, 1999) and that eucalyptus leachates may be toxic to shredders (CANHOTO and LARANJEIRA, 2007) we suggest that eucalyptus leaves were mainly used as a substratum rather than as food source. The observed dominant microbial breakdown of both leaf types (ratio $k \mathrm{CM}: k$ $\mathrm{FM} \approx 1$ ) points in this direction.

In conclusion, the breakdown of fire exposed leaves was clearly promoted by fungi and accelerated by physical fragmentation. It is nevertheless noteworthy that no significant differences were found in the breakdown rates of leaves contained in bags with different mesh size. It seems that both mesh sizes were similarly affected by the current; the reduced number of invertebrates did not seem to contribute to stimulate leaves degradation in coarse mesh bags. FERREIRA et al. (2006b) in a study performed in artificial channels demonstrated that, in the absence of invertebrates, no significant differences in $k$ values were also found between coarse and fine mesh bags in low or high current.

The results reported here suggest that changes in quality of allochthonous inputs in postfire streams do not result in altered ecosystem functioning in a short term. However, changes in environmental conditions, community structure and/or stream energy pathways are likely to occur after fires (Minshall et al., 2001a; Minuc and Minshall, 2005) modulating the present results - this study was conducted, in autumn, in an eucalyptus stream unaffected by fire events. Further investigation on postfire scenarios and comparative long-term studies using eucalyptus streams affected and unaffected by fire are needed for a correct evaluation of the structural and functional changes in stream ecosystems affected by fires. 


\section{Acknowledgements}

We thank DR. Francisco Gírio for lignin extraction, Victor Paiva for calorific content determinations and ELSA RODRIGUES for ion chromatography and HPLC analyses. Financial support by the Fundação para a Ciência e Tecnologia (Programa POCTI2010/SFRH/BD/11350/2002) to VF and financial support from IMAR is gratefully acknowledged.

\section{References}

APHA, 1995: Standard Methods for the Examination of Water and Wastewater, 19th edn. EATON A. E., L. S. Clesceri and A. E. Greennerg (eds), Washington, D. C.

Baldy, V., M. O. Gessner and E. Chauvet, 1995: Bacteria, fungi and breakdown of leaf litter in a large river. - Oikos 74: 93-102.

BÄRLOCHER, F. and M. SCHWEIZER, 1983: Effects of leaf size and decay rate on colonization by aquatic hyphomycetes. - Oikos 41: 205-210.

BÄRLOCHER, F., 1991: Fungal colonization of fresh and dried leaves in the River Teign (Devon, England). - Nova Hedwigia 52: 349-357.

BÄrlocher, F., 1992: Community organization. - In: Bärlocher, F. (ed.) The ecology of aquatic hyphomycetes. Springer-Verlag, Berlin, pp. 38-76.

BÄrlocher, F., C. CANHOTO and M. A. S. GRAÇA, 1995: Fungal colonization of alder and eucalypt leaves in two streams in Central Portugal. - Arch. Hydrobiol. 133: 457-470.

BÄRLOCHER, F. and M. A. S. GRAÇA, 2002: Exotic riparian vegetation lowers fungal diversity but not leaf decomposition in Portuguese streams. - Freshwat. Biol. 47: 1123-1135.

CANHoto, C. and M. A. S. GRAÇA, 1995: Food value of introduced eucalypt leaves for a Mediterranean stream detritivore: Tipula lateralis. - Freshwat. Biol. 34: 209-214.

CAnHoto, C. and M. A. S. GraÇA, 1996: Decomposition of Eucalyptus globulus leaves and three native leaf species (Alnus glutinosa, Castanea sativa and Quercus faginea) in a Portuguese low order stream. - Hydrobiologia 333: 79-85.

CANHOto, C. and M. A. S. GRAÇA, 1999: Leaf barriers to fungal colonization and shredders (Tipula lateralis) consumption of decomposing Eucalyptus globulus. - Microb. Ecol. 37: 1631-72.

CANHOTO, C. and C. LARANJeIRA, 2007: Leachates of Eucalyptus globulus in intermittent streams affect water parameters and invertebrates. - Internat. Rev. Hydrobiol. 92: 173-182.

Certini, G., 2005: Effects of fire on properties of forest soils: a review. - Oecologia 143: 1-10.

Chauvet, E., E. Fabre, A. Elosegui and J. Pozo, 1997: The impact of eucalypt on the leaf-associated aquatic hyphomycetes in Spanish streams. - Can. J. Bot. 75: 880-887.

Chauvet, E. and K. Suberkropp, 1998: Temperature and sporulation of aquatic hyphomycetes. - Appl. Environ. Microbiol. 64: 1522-1525.

Clarke, K. R. and R. N. Gorley, 2001: Primer v5: User Manual/Tutorial. - Primer-E Ltd., Plymouth, UK.

Díez, J., A. Elosegi, E. Chauvet and J. Pozo, 2002: Breakdown of wood in the Agüera stream. - Freshwat. Biol. 47: 2205-2215.

D. G. F. - DiReCÇÃo GeRAL Florestas (2005) http://www.dgrf.min-agricultura.pt.

DoERr, S. H. and A. CERDÀ, 2005: Fire effects on soil system functioning: new insights and future challenges. - Internat. J. Wildland Fire 14: 339-342.

Ferreira, A. J. D., C. O. A. Coelho, A. K. Boulet and F. P. Lopes, 2005: Temporal patterns of solute loss following wildfires in Central Portugal. - Internat. J. Wildland Fire 14: 401-414.

Ferreira, V., A. Elosegi, V. Gulis, J. Pozo and M. A. S. GraÇA, 2006a: Eucalyptus plantations affect fungal communities associated with leaf-litter decomposition in Iberian streams. - Archiv. Hydrobiol. 166: $467-490$.

Ferreira, V., M. A. S. GraÇA, J. L. M. P. DE Lima and R. Gomes, 2006b: Role of physical fragmentation and invertebrate activity in the breakdown rate of leaves. - Archiv. Hydrobiol. 165: 493-513.

Gessner, M. O. and E. Chauvet, 1993: Ergosterol-to-biomass conversion factors for aquatic hyphomycetes. - Appl. Environ. Microbiol. 59: 502-507.

Gessner, M. O., M. Thomas, A. M. Jean-Louis and E. Chauvet, 1993: Stable succecional patterns of aquatic hyphomycetes on leaves decaying in a summer cool stream. - Mycol. Res. 97: 163-172. 
Gessner, M. O. and E. Chauvet, 1994: Importance of microfungi in controlling breakdown rates of leaf litter. - Ecology 75: 1807-1817.

Gessner, M. O. and A. L. Schmitt, 1996: Use of solid-phase extraction to determine ergosterol concentrations in plant tissue colonized by fungi. - Appl. Environ. Microbiol. 62: 415-419.

Gessner, M. O., E. Chauvet and M. Dobson, 1999: A perspective on leaf litter breakdown in streams. - Oikos 85: 377-383.

Goering, H. K. and P. J. VAn Soest, 1970: Forage fiber analysis (apparatus, reagents, procedures and some applications). - USDA Agricultural Handbook No. 379.

Graça, M. A. S., C. Cressa, M. O. Gessner, M. J. Feio, K. A. Callies and C. Barrios, 2001: Food quality, feeding preferences, survival and growth of shredders from temperate and tropical streams. Freshwat. Biol. 46: 947-957.

GraÇa M. A. S., F. Bärlocher and M. O. Gessner (eds), 2005: Methods to Study Litter Decomposition. A Practical Guide. Springer, the Netherlands.

Gulis, V. and K. Suberkropp, 2003a: Leaf litter decomposition and microbial activity in nutrientenriched and unaltered reaches of a headwater stream. - Freshwat. Biol. 48: 123-134.

Gulis, V. and K. SuBERKROPP, 2003b: Effect of inorganic nutrients on relative contributions of fungi and bacteria to carbon flow from submerged decomposing leaf litter. - Microbiol. Ecol. 45: 11-19.

Hauer, F. R. and C. N. Spencer, 1998: Phosphorus and Nitrogen Dynamics in Streams Associated With Wildfire: a Study of Immediate and Longterm Effects. - Internat. J. Wildland Fire 8: 183-198.

HIEBER, M. and M. O. GeSSNER, 2002: Contribution of stream detritivores, fungi, and bacteria to leaf breakdown based on biomass estimates. - Ecology 83: 1026-1038.

Minuc, T. B. and G. W. Minshall, 1995: Trophic generalists vs trophic specialists- implications for food-web dynamics in postfire streams. - Ecology 76: 2361-2372.

Minuc, T. B. and G. W. Minshall, 2005: The trophic basis of reference and post-fire stream food webs 10 years after wildfire in Yellowstone National Park. - Aquatic Sci. 67: 541-548.

Minshall, G. W., J. T. Brock, D. A. Andrews and C. T. Robinson, 2001a: Water quality, substratum and biotic responses of five central Idaho (USA) streams during the first year following the Mortar Creek fire. - Internat. J. Wildland Fire 10: 185-199.

Minshall, G. W., C. T. Robinson, D. E. Lawrence, D. A. Andrews and J. T. Brock, 2001b: Benthic macroinvertebrate assemblage in five central Idaho (USA) streams over a 10-year period following disturbance by wildfire. - Internat. J. Wildland Fire 10: 201-213.

Minshall, G. W., K. E. Bowman and C. D. Myler, 2003a: Effects of wildfire on Yellowstone stream ecosystems: a retrospective view after a decade. pp. 164-173 - In: GALlEY, K. E. M., KLingeR, R. C. and Sugihara (eds.) Proceedings of fire conference 2000: the first national congress on fire ecology, prevention, and management. Miscellaneous Publication No. 13, Tall Timbers Research Station, Tallahassee, FL.

MinshaLl, G. W., 2003b: Responses of stream benthic macroinvertebrates to fire. - Forest Ecol. Man. 178: $155-161$.

Molinero, J., J. Pozo and E. GonzÁLez, 1996: Litter breakdown in streams of the Agüera catchment: influence of dissolved nutrients and land use. - Freshwat. Biol. 36: 745-756.

Molinero, J. and J. Pozo, 2003: Balances de hojarasca en dos arroyos forestados: impacto de las plantaciones de eucalipto en el funcionamiento ecológico de un sistema lótico. - Limnetica 22: 63-70.

NiYogy, D. K., K. S. Simon and C. R. TownSEnd, 2003: Breakdown of tussock grass in streams along a gradient of agricultural development in New Zealand. - Freshwat. Biol. 48: 1698-1708.

Paiva, V. H., J. A. Ramos, T. Catry, P. Pedro, R. Medeiros and J. Palma, 2006: Influence of environmental factors and energetic value of food on little stern Sterna albifrons chick growth and food delivery. - Bird Study 53: 1-11.

PASCOAL, C. and F. CÁssIo, 2004: Contribution of fungi and bacteria to leaf litter decomposition in a polluted river. - Appl. Environ. Microbiol. 70: 5266-5273.

Pozo, J., E. GonZÁlez, J. DíEZ and A. Elosegi, 1997a: Leaf-litter budgets in two contrasting forested streams. - Limnetica 13: 77-84.

Pozo, J., E. González, J. R. Díez, J. Molinero and A. Elosegui, 1997b: Inputs of particulate organic matter to streams with different riparian vegetation. - J. N. Am. Benthol. Soc. 16: 602-611.

Pozo, J., A. Basaguren, A. Elósegui, J. Molinero, E. Fabre and E. Chauvet, 1998: Afforestation with Eucalyptus globulus and leaf litter decomposition in streams of northern Spain. - Hydrobiologia 373/374: 101-109.

Regueira, N. L., J. A. R. AÑon, J. P. Castiñeiras and A. V. Diez, 2002: Determination of risk indices corresponding to eucalyptus in Galicia using bomb calorimetry. - Thermochimica Acta 394: 267-278. 
Royer, T. V. and W. Minshall, 2001: Effects of nutrient enrichment and leaf quality on the breakdown of leaves in a hardwater stream. - Freshwat. Biol. 46: 603-610.

Stelzer, R. S., J. HefFernan and G. E. Likens, 2003: The influence of dissolved nutrients and particulate organic matter quality on microbial respiration and biomass in a forest stream. - Freshwat. Biol. 48: 1925-1937.

Stephens, S. L., T. Meixner, M. Poth, B. McGurk and D. Payne, 2005. Prescribed fire, soils, and stream water chemistry in a watershed in the Lake Tahoe Basin, California. - Internat. J. Wildland Fire 13: 27-35.

Tachet, H., P. Richoux, M. Bournaud and F. Usseglio-Polatera, 2000: Invertébrés d'eau douce. Systématique, biologie, écologie. - CNRS Editions, Paris.

WeBSTER, J. and E. F. BeNFIELD, 1986: Vascular plant breakdown in freshwater ecosystems. - Ann. Rev. Ecol. Syst. 17: 567-594.

ZAR, J. H., 1999: Biostatistical Analysis, 4th edn. Prentice-Hall, Englewood Cliffs, NJ.

Manuscript received August 1st, 2006; revised December 27th, 2006; accepted January 17th, 2007 